\title{
MANAGEMENT OF BASAL CELL CARCINOMA OF FACE
}

\author{
Ratnakar Sharma1, Sanjay Sharma², Rishabh Sharma3, Raheel Hussan ${ }^{4}$
}

${ }^{1}$ Associate Professor, Department of General Surgery, GMC, Jammu, Jammu and Kashmir, India. ${ }^{2}$ Assistant Professor, Department of General Surgery, GMC, Jammu, Jammu and Kashmir, India.

${ }^{3}$ Resident, Department of General Surgery, GMC, Jammu, Jammu and Kashmir, India.

${ }^{4}$ Resident, Department of General Surgery, GMC, Jammu, Jammu and Kashmir, India.

\author{
BACKGROUND \\ ABSTRACT \\ Basal Cell Carcinoma is a locally invasive, slowly spreading tumour which rarely metastasises, arising in the epidermis or hair \\ follicles, the cells usually resembling the basal cells of the epidermis. The Basal Cell Carcinoma in North Indian population usually \\ involves head and neck region. The management of Basal Cell Carcinoma of face requires excision of lesion with healthy margin s \\ and resurfacing the defect by split skin graft/ flap coverage. \\ Aims and Objectives: \\ 1. To evaluate the epidemiology of Basal Cell Carcinoma of face. \\ 2. To evaluate various modalities of coverage of the defect following surgical excision of Basal Cell Carcinoma of face.
}

\section{MATERIALS AND METHODS}

This case series was conducted in the Department of Surgery, Govt. Medical College Jammu, J and K, India and included 50 patients having been diagnosed with Basal Cell Carcinoma of face (histopathology proven) admitted in surgery ward from November 2015 to October 2017 (Prospective study). All patients underwent surgical excision with a $5 \mathrm{~mm}$ healthy margin followed by reconstruction either by skin graft $(12 \%)$ or flap coverage $(88 \%)$.

\section{RESULTS}

Majority of the patients had restoration of anatomy and normal function after reconstructive procedures with colour and contour matching of that of the recipient site. No major complication was encountered in any of the patients.

\section{CONCLUSION}

Basal Cell Carcinoma is treated with surgical excision followed by adequate coverage of the defect by a modality which should not only be functionally adequate, but also aesthetically appealing. Flaps are a versatile modality of reconstruction with the choice of flap being governed by the site and size of the defect post tumour excision.

\section{KEY WORDS}

Basal Cell Carcinoma, Excision, Reconstruction of Defects.

HOW TO CITE THIS ARTICLE: Sharma R, Sharma S, Sharma R, et al. Management of basal cell carcinoma of face. J. Evolution Med. Dent. Sci. 2018;7(23):2749-2752, DOI: 10.14260/jemds/2018/621

\section{BACKGROUND}

Jacob Arthurian in 1827 first coined the term rodent ulcer to describe what we now know as Basal Cell Carcinoma. ${ }^{1}$ Basal Cell Carcinoma is the most common skin cancer among whites. $^{2}$ It accounts for $75 \%$ of all skin cancers. Basal Cell Carcinoma contributes to $20 \%-30 \%$ of skin malignancies in Asian Indians. ${ }^{3}$ The Basal Cell Carcinoma has a high propensity to involve the sun exposed areas of head and neck with a high percentage of $91.2 \%$. The most common location being the medial/ lateral canthus of eye. ${ }^{4}$ Individuals with a Basal Cell Carcinoma over the face typically presents with a shiny, pearly skin nodule. However, superficial Basal Cell Carcinoma can present as a red patch similar to eczema. Infiltrative or morphea form basal cell cancers can present as skin thickening or scar tissue making diagnosis difficult without using tactile sensation and a skin histopathology. ${ }^{5}$

'Financial or Other Competing Interest': None.

Submission 14-05-2018, Peer Review 25-05-2018,

Acceptance 28-05-2018, Published 04-06-2018.

Corresponding Author:

Dr. Sanjay Sharma,

Assistant Professor, Department of General Surgery,

Government Medical College, Jammu-180001

Bakshi Nagar, Jammu and Kashmir, India.

E-mail: drsanjay912@gmail.com

DOI: $10.14260 /$ jemds $/ 2018 / 621$
Most Basal Cell Carcinomas are slow growing, relatively non-aggressive tumours; a minority have an aggressive behaviour with local tissue destruction and metastasis. ${ }^{6}$ Although, prevalence of metastasis and mortality is very low. 7,8 Basal Cell Carcinomas may grow aggressively causing extensive tissue destruction. ${ }^{9}$ The management of Basal Cell Carcinoma of the face requires excision of the lesion with healthy margins and resurfacing the defect by skin graft/ flap coverage. Reconstruction of various facial defects including those of nose, eyelids, canthi, cheeks and ear following resection of Basal Cell Carcinomas involving face has been described in various studies. ${ }^{10,11,12}$

In the present study, an attempt has been made to describe in detail the management of patients with Basal Cell Carcinomas involving face. The evaluation of various reconstructive modalities for coverage of the defects arising out of excision of the Basal Cell Carcinoma over the face has been made.

\section{Objectives}

- To evaluate the epidemiology of Basal Cell Carcinoma of face.

- To evaluate various modalities of coverage of the defect following surgical excision of Basal Cell Carcinoma of face. 


\section{MATERIALS AND METHODS}

This case series is done on 50 patients having been diagnosed with Basal Cell Carcinoma of face (Histopathology proven) requiring surgical excision followed by reconstruction of the defects admitted in Postgraduate Department of Surgery, Government Medical College, Jammu (J and $\mathrm{K}$ ) from November 2015 to October 2017. The patients were studied prospectively. Detailed history of the patient, examination of the lesion followed by investigations for anaesthesia was done in all the cases. All the patients underwent surgical excision of the lesion with a $5 \mathrm{~mm}$ margin all around the lesion. The defect was then suitably covered by either skin graft or flap. Flap division and inset if required was done after interval of three weeks. The excised specimen was assessed for margin and depth clearance post-operatively. Follow-up of patients was done clinically at monthly intervals for first three months and then after every three months.

\section{Inclusion Criteria}

All patients presenting with histopathology proven Basal Cell Carcinoma of the face.

\section{Exclusion Criteria}

1. Extensive disease with gross involvement of the orbit or intra-orbital infiltration.

2. Patients having multifocal lesions.

\section{RESULTS}

\begin{tabular}{|c|c|c|}
\hline Age Group & No. of Patients & Percentage (\%) \\
\hline $21-30$ years & 2 & 4 \\
\hline $31-40$ years & 2 & 4 \\
\hline 41-50 years & 14 & 28 \\
\hline 51-60 years & 18 & 36 \\
\hline 61-70 years & 8 & 16 \\
\hline 71-80 years & 6 & 12 \\
\hline Total & 50 & 100 \\
\hline \multicolumn{3}{|c|}{ Table 1. Age distribution of Patients } \\
\hline
\end{tabular}

Maximum number of patients were in the age group of 51-60 years (36\%) followed by 41 - 50 years of age (28\%). The average age was 54.4 years.

Out of the 50 patients, 32 (64\%) were male and 18 (36\%) were females, male: female ratio of about 1.7: 1 . Out of all the patients, majority were residents of rural areas $(72 \%)$.

Maximum patients were either labourers or farmers (80\%), who were exposed to sunlight for prolonged durations.

\begin{tabular}{|c|c|c|}
\hline Interval & Number & Percentage (\%) \\
\hline < 6 Months & 6 & 12 \\
\hline > 6 Months & 44 & 88 \\
\hline Total & $\mathbf{5 0}$ & $\mathbf{1 0 0}$ \\
\hline \multicolumn{2}{|c|}{ Table 2. Time Interval between Onset of Lesion and } \\
Presentation to the OPD \\
\hline
\end{tabular}

In our study, $88 \%$ of patients presented to the OPD for evaluation more than 6 months after the onset of the lesion with the average duration of delay being 8.4 months.

The commonest site of the lesion was eyelid [56\%] followed by nose, cheek and forehead being $28 \%, 12 \%$ and $4 \%$, respectively.

\begin{tabular}{|c|c|c|}
\hline Coverage Modality & Patients & Percentage (\%) \\
\hline Skin Graft & 6 & 12 \\
\hline Flap & 44 & 88 \\
\hline Total & $\mathbf{5 0}$ & $\mathbf{1 0 0}$ \\
\hline \multicolumn{2}{|c|}{ Table 3. Coverage Modality Post Excision }
\end{tabular}

Flaps were the most common modality of coverage (88\%) after excision of Basal Cell Carcinoma of face.

\begin{tabular}{|c|c|c|}
\hline Type of Flap & $\begin{array}{c}\text { Number of } \\
\text { Patients }\end{array}$ & $\begin{array}{c}\text { Percentage } \\
\text { (\%) }\end{array}$ \\
\hline Forehead flap & 18 & 41 \\
\hline Nasolabial flap & 12 & 27.3 \\
\hline Fricke's flap & 6 & 13.7 \\
\hline $\begin{array}{c}\text { Superficial temporal artery } \\
\text { flap }\end{array}$ & 4 & 9 \\
\hline Free radial artery flap & 2 & 4.5 \\
\hline $\begin{array}{c}\text { Combined nasolabial and } \\
\text { forehead flap }\end{array}$ & 2 & 4.5 \\
\hline Total & $\mathbf{4 4}$ & $\mathbf{1 0 0}$ \\
\hline Table 4. Type of Flap \\
\hline
\end{tabular}

Forehead flap was the commonest modality of coverage [41\%] followed by nasolabial flap [27.3\%].

Patients undergoing excision of lesion followed by coverage with skin graft took 2 weeks to recover, whilst the recovery period was 4 weeks in the patients undergoing flap coverage as a reconstructive modality.

No major complication was noted in any of the patients. Hair growth was noticed in 6 cases where forehead flap was used for coverage of the defect due to extension of the flap into the hair bearing area of the scalp. Flap bulk was noticed in the case requiring combined nasolabial and forehead flap for coverage of nasal defect.

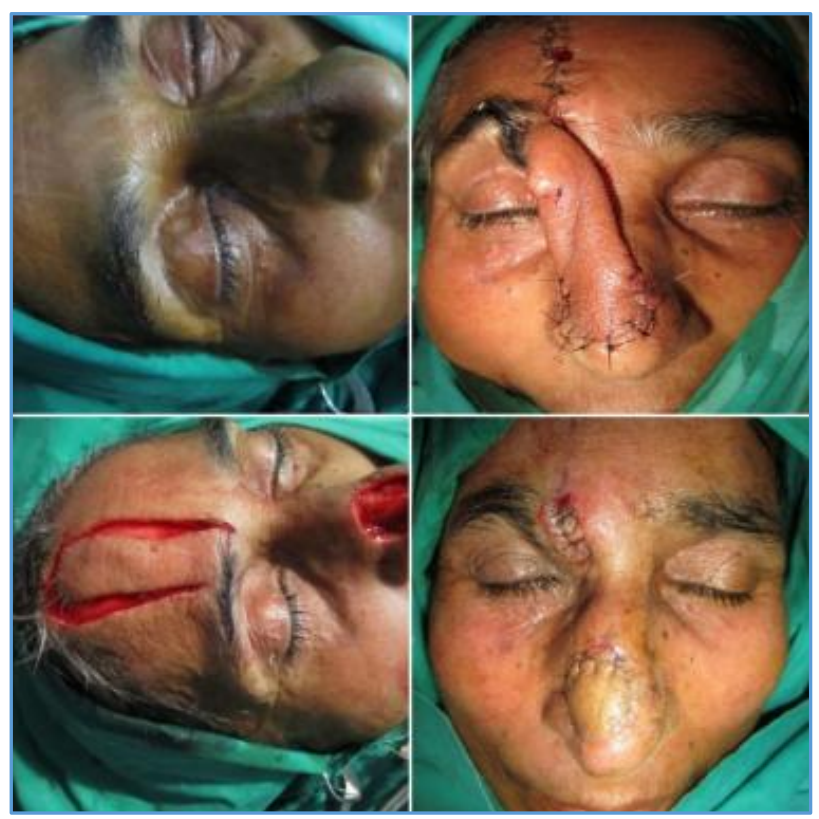

Plate 1. Forehead Flap for Reconstruction of Post Excision Nasal Defect of Basal Cell Carcinoma 


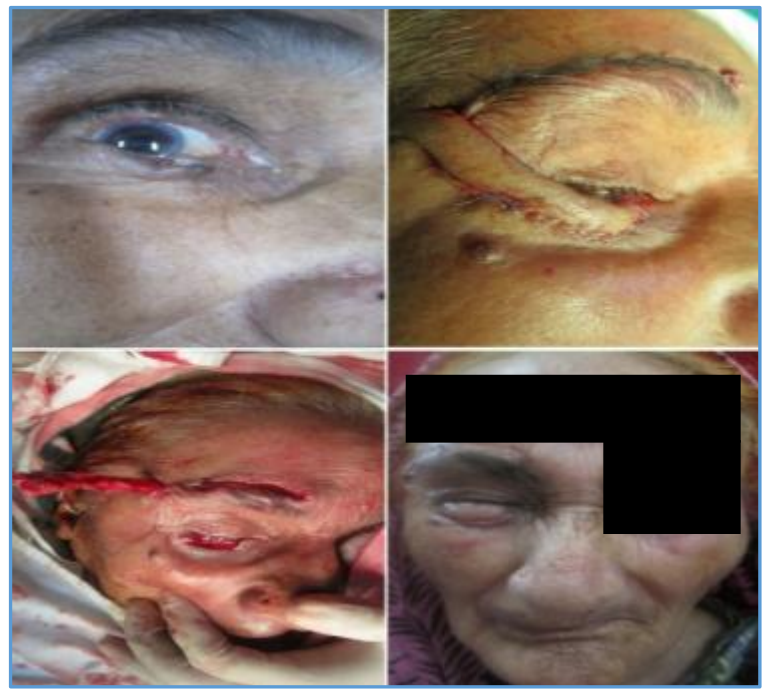

Plate 2. Fricke's Flap for Lower Eyelid Reconstruction after Excision of Lower Eyelid Basal Cell Carcinoma

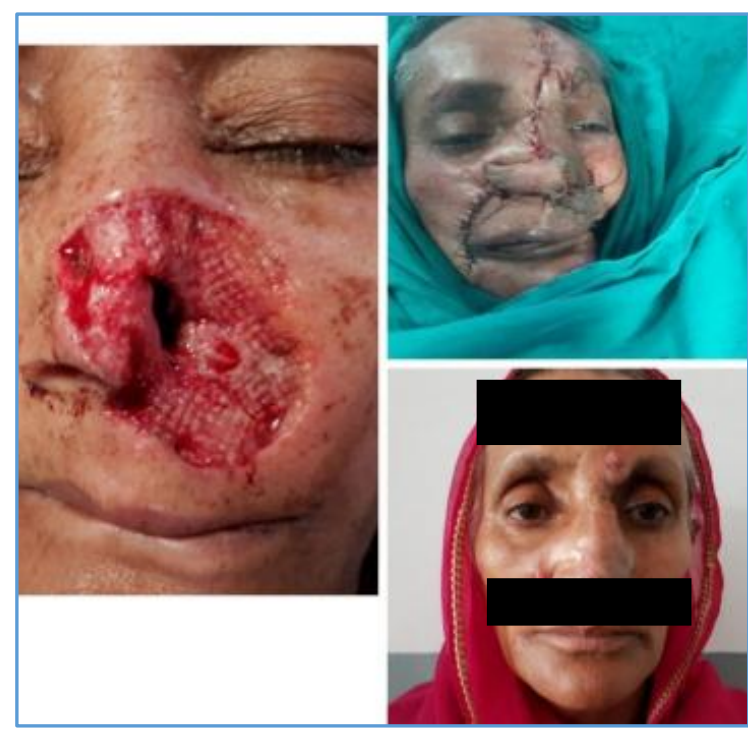

Plate 3. Combined Nasolabial and Forehead Flap for Nasal Reconstruction of Post Excision Defect of Nasal Basal Cell Carcinoma
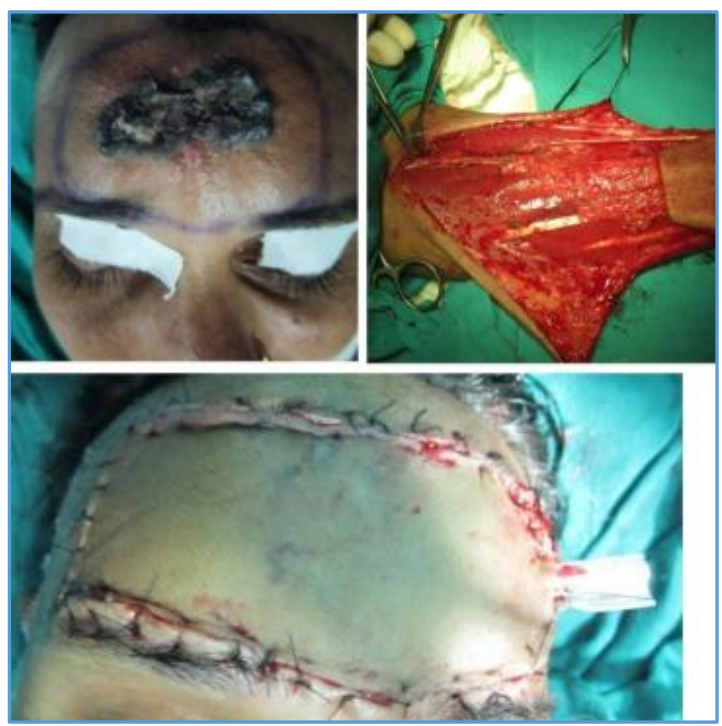

Plate 4. Free Radial Artery Flap for Forehead Reconstruction following Excision of Basal Cell Carcinoma of Forehead

\section{DISCUSSION}

Basal Cell Carcinomas are the most frequent skin cancers usually occurring on the sun exposed of the body with maximum being located over the face. In our study, 50 cases of Basal Cell Carcinoma of face needing excision and coverage were included. Maximum number of patients were in age group of 51 - 60 years. Mean age of patients was 54.4 years. The youngest patient was 29 years old male, whereas the oldest patient was 78 years old male. The relationship between the old age and the incidence of Basal Cell Carcinoma is well established in studies by other authors.13,14,15 Males outnumbered the females in our study group with males accounting for $64 \%$ of the cases. This finding goes well with the other study groups.4,16,17 The incidence of Basal Cell Carcinoma was highest in labourers or farmers (80\%). Szewczyk M et al ${ }^{18}$ in their study on 312 patients treated for head and neck Basal Cell Carcinomas observed that farmers accounted for $33 \%$ of all the patients. The lower eyelid was the most common site of Basal Cell Carcinoma (56\%) followed by nose (28\%) and cheek (12\%). Forehead was the least common site. Allali J and D'Hermies F19 in their study found that Basal Cell Carcinoma accounted for approximately $90 \%$ of the eyelid tumours and most frequently involved the lower eyelid. Jung Hun Choi et al 20 found the most common location of the occurrence of Basal Cell Carcinoma is face to the nasal unit followed by orbital unit. In our study the tumour excision was done with a circumferential margin of $5 \mathrm{~mm}$, which is close to the margins in other studies. 21,22

Flap coverage was employed as a method of reconstruction of the defects following excision. Out of 44 patients undergoing flap coverage, forehead flap was the most commonly used for reconstruction. Six patients undergoing forehead flap for repair had hair growth at the recipient site. The role of forehead flap in reconstruction of facial defects following resection of Basal Cell Carcinoma has been established in other studies too. 14,23,24

Nasolabial flap was the second most common modality of coverage $(27.3 \%)$ in our study with no complications observed during the follow-up period. The role of nasolabial flap for the reconstruction of lower eyelid/ nasal ala has been stressfully done by other authors too. 25,26

Fricke's flap was the method of reconstruction in six cases $(13.7 \%)$ with no complication in post-operative period in our study. Fricke's flap for reconstruction of eyelids and canthi has been used in other studies too. 27,28

Superficial temporal artery flap was used in four cases for reconstruction of defect following excision of Basal Cell Carcinoma over the cheek with no post-operative complications. $\mathrm{Xu} M$ et $\mathrm{al}^{29}$ reconstructed 12 cases of zygomatic cheek defects using superficial temporal artery flap successfully.

Two large nasal defects occurring after excision of Basal Cell Carcinoma required coverage using combination of forehead and nasolabial flaps. The flaps survived postoperatively. Zelken JA et al used combined nasolabial and forehead flap to cover defects involving the upper lip and nose in 6 patients. ${ }^{30}$

None of our patients had recurrence of the lesion during followup. 


\section{CONCLUSION}

We conclude that Basal Cell Carcinoma of face commonly affects labourers/farmers, the lower eyelid being the most common affected anatomical site, flaps are the most versatile reconstructive modality providing a durable coverage with anatomical and cosmetic acceptance with minimal morbidity after doing an oncological resection of the tumour site.

\section{REFERENCES}

[1] Malik V, Goh KS, Leong S, et al. Risk and outcome analysis of 1832 consecutively excised Basal Cell Carcinomas in a tertiary referral plastic surgical unit. J of Plastic Reconstructive and Aesthetic Surg 2010;63(12):2057-63.

[2] Telfer NR, Colver GB, Bowers PW. Guidelines for the management of Basal Cell Carcinoma. British Association of Dermatologists. $\mathrm{Br} \mathrm{J}$ Dermatol 1999;141(3):415-23.

[3] Golster HM Jr, Neal K. Skin cancer in skin of color. J Am Acad Dermatol 2006;55(5):741-60.

[4] Malhotra P, Singh A, Ramesh V. Basal Cell Carcinoma in North Indian population: clinicopathological review and immunohistochemical analysis. Indian J Dermatol Venereal Leprol 2011;77(3):328-30.

[5] Boyd AS, Shry Y, King LE Jr. Basal Cell Carcinoma in young women: an evaluation of the association of tanning bed use and smoking. J of the American Academy of Dermatol 2002;46(5):706-9.

[6] Miller SJ. Biology of Basal Cell Carcinoma (part 1). J Am Acad Dermatol 1991;24(1):1-13.

[7] Shrivastava R, Singh KK, Shrivastava M. Soft tissue metastasis in Basal Cell Carcinoma. Indian J Dermatol 2007;52(4):206-08.

[8] Golster HM Jr, Brodland DG. The epidemiology of skin cancer. Dermatol Surg: Official Pub Am Soc for Dermatol Surg 1996;22(3):217-26.

[9] Grossman D, Leffell DJ. The molecular basis of nonmelanoma skin cancer: new understanding. Arch Dermatol 1997;133(10):1263-70.

[10] Sagarelli AC, Belini P, Multinu A, et al. Reconstruction of nasal skin cancer defects with local flaps. J Skin Cancer 2011;2011:181093.

[11] Hassan IM, Hassan EL-Maleek, Abd Doaa. Reconstruction after removal of Basal Cell Carcinoma. J Am Science 2012;8(7):42-7.

[12] Wang Y, Long X, Wang X. Reconstruction of periorbital soft tissue defect with reversed superficial temporal artery island flap. Ann Plast Surg 2014;73(Suppl 1):S70-S3.

[13] Rahbari H, Mehregan AH. Basal cell epithelioma (carcinoma) in children and teenagers. Cancer 1982;49(2):350-3.

[14] Rao J, Deora H. Surgical excision with forehead flap as single modality treatment for basal cell cancer of central face: single institutional experience of 50 cases. J Skin Cancer 2014;2014:320792.
[15] Kumar S, Mahajan BB, Kaur S, et al. A study of Basal Cell Carcinoma in south Asians for risk factors and clinicopathological characterisation: a hospital based study. Article ID 173582, J Skin Cancer 2014: p. 9.

[16] Meibodi NT, Maleki M, Javidi Z, et al. Clinicopathological evaluation of radiation induced Basal Cell Carcinoma. Indian J Dermatol 2008;53(3):137-9.

[17] Panda S. Non-melanoma skin cancer in India: current scenario. Indian J Dermatol 2010;55(4):373-8.

[18] Szewczyk M, Pazdrowski J, Golusinski P. Basal Cell Carcinoma in farmers: an occupation group at high risk. Int Arch Occup Environ Health 2016;89(3):497501.

[19] Allali J, D’Hermies F, Renard G. Basal Cell Carcinomas of the eyelids. Ophthalmologica 2005;219(2):57-71.

[20] Choi JH, Kim YJ, Kim H, et al. Distribution of Basal Cell Carcinoma and squamous cell carcinoma by facial aesthetic unit. Arch Plast Surg 2013;40(4):387-91.

[21] Thomas DJ, King AR, Peat BG. Excision margins for non-melanotic skin cancer. Plast Reconstr Surg 2003;112(1):57-63.

[22] Luz FB, Ferron C, Cardoso GP. Surgical treatment of Basal Cell Carcinoma: an algorithm based on the literature. An Bras Dermatol 2015;90(3):377-83.

[23] Correa BJ, Weathers WM, Wolfswinkel EM, et al. The forehead flap: the gold standard of nasal soft tissue reconstruction. Semin Plast Surg 2013;27(2):96-103.

[24] Elshamma NA, Al-Qabbani A, Alkatan HM, et al. The use of forehead flaps in the management of large Basal Cell Carcinomas of medial canthus/medial lower eyelid in Saudi patients. Saudi J Ophthalmol 2013;27(3):223-5.

[25] Lazaridis N, Zouloumis L, Venetis G, et al. The inferiorly and superiorly based nasolabial flap for the reconstruction of moderate-sized oronasal defects. J Oral Maxillofac Surg 1998;56(11):1255-9.

[26] Bilal M, Irfanullah, Ehsanullah. Nasolabial flap: a workhorse for the reconstruction of nasal ala after tumour resection. JKCD 2014;5(1):10-15.

[27] McCord D. Upper eyelid reconstruction. In: McCord D, edr. Eyelid surgery. Principles and techniques. $1^{\text {st }}$ edn. Philadelphia: Lippincott-Raven 1995: p. 252-69.

[28] Wilcsek G, Leatherbarrow B, Halliwell M, et al. The RITE use of the Fricke flap in periorbital reconstruction. Eye (Lond) 2005;19(8):854-60.

[29] Xu M, Yang C, Li JH, et al. Reconstruction of the zygomatic cheek defects using a flap based on the pretragal perforator of superficial temporal artery. J Plast Reconstr and Aest Surg 2014;67(11):1508-14.

[30] Zelken JA, Reddy SK, Chang CS, et al. Nasolabial and forehead flap reconstruction of contiguous alar-upper lip defects. J Plast Reconstr Aesthet Surg 2017;70(3):330-5. 